\title{
MALDI-TOF mass spectroscopy of yeasts and filamentous fungi for research and diagnostics in the agricultural value chain
}

\author{
David Drissner ${ }^{1}$ and Florian M. Freimoser ${ }^{2^{*}}$
}

\begin{abstract}
Matrix-assisted laser desorption ionization time-of-flight mass spectrometry (MALDI-TOF MS; MALDI biotyping) has become a standard tool for the accurate, rapid, and economical identification of pathogens in the clinical diagnostics laboratory. The method is continuously being improved, and new applications for distinguishing strains, identifying metabolites or functional characteristics (e.g., antibiotic resistance), and detecting microbes directly in patient samples have been developed. Adopting these methods in other disciplines than clinical diagnostics, for example, in agriculture, food safety and quality testing, or ecology, will open up new opportunities for diagnostics and research. This review focuses on MALDI-TOF MS approaches for the identification of yeasts and filamentous fungi. In contrast to bacterial diagnostics, MALDI biotyping of fungi is more challenging and less established. We thus start by discussing the role of MALDI-TOF MS as a tool for species identification; in particular with respect to DNA-based identification methods. The review then highlights the value of custom-made reference spectra for MALDI biotyping and points out recent advancements of MALDI-TOF MS, mainly from the field of clinical diagnostics that may be adopted and used for fungal diagnostic challenges. The overview ends with a summary of MALDI-TOF MS studies of yeasts and filamentous fungi of agricultural relevance.
\end{abstract}

Keywords: Agriculture, MALDI-TOF MS, Biotyping, Diagnostics, Filamentous fungi, Yeast

\section{Introduction}

Matrix-assisted laser desorption ionization time-offlight mass spectrometry (MALDI-TOF MS; also called MALDI biotyping) has become increasingly popular for the identification of microorganisms and their functions and is now approved for the routine identification of bacteria and fungi in clinical diagnostic laboratories [1-3]. It is the goal of this review to highlight recent technological advancements of MALDI biotyping and to illustrate applications of this tool for research in agriculture and the agricultural value chain. This outlook focuses on MALDI-TOF MS applications in mycology, because these are usually more demanding than bacterial identifications $[4,5]$ and will thus greatly benefit from the recent

\footnotetext{
*Correspondence: florian.freimoser@agroscope.admin.ch

2 Research Division Plant Protection, Agroscope, Schloss 1,

8820 Wädenswil, Switzerland

Full list of author information is available at the end of the article
}

advances in bacterial MALDI-TOF MS diagnostics. In this context, it is important to note that MALDI-TOF MS is not an alternative to DNA sequence-based species identification, but rather a complementary method. In order to make use and realize the potential of MALDITOF MS it may thus be helpful bringing to mind the advantages and disadvantages of this method; in particular as compared to DNA-based assays and techniques.

\section{MALDI biotyping and DNA-based identification complement each other}

The identification of fungi usually involves a DNA sequence-based analysis that determines the identity of a given isolate based on sequence similarity; often taking advantage of the universal fungal barcode sequence of the nuclear ribosomal internal transcribed spacer (ITS) [6]. Second and third generation sequencing techniques now allow the sequencing of thousands or millions of barcodes, or even entire genomes, in parallel and such 
high-throughput technologies are available to virtually every laboratory. These barcode (amplicon) and metagenome sequencing methods allow identifying hundreds or thousands of species simultaneously and are thus powerful tools to describe the composition of entire microbial communities (Fig. 1a) [7-9]. However, although massive parallel DNA sequencing generates a wealth of data, often more data are generated than needed and storage of the data and extraction of the required information is challenging and often limiting [10]. In addition, preparation and quality control of the template libraries for DNA sequencing is time consuming and costly (Table 1). In specific cases, for the repeated identification of a defined number of species, it may thus be best not to generate the largest amount of data, but rather to generate exactly the amount of data needed in the fastest and most

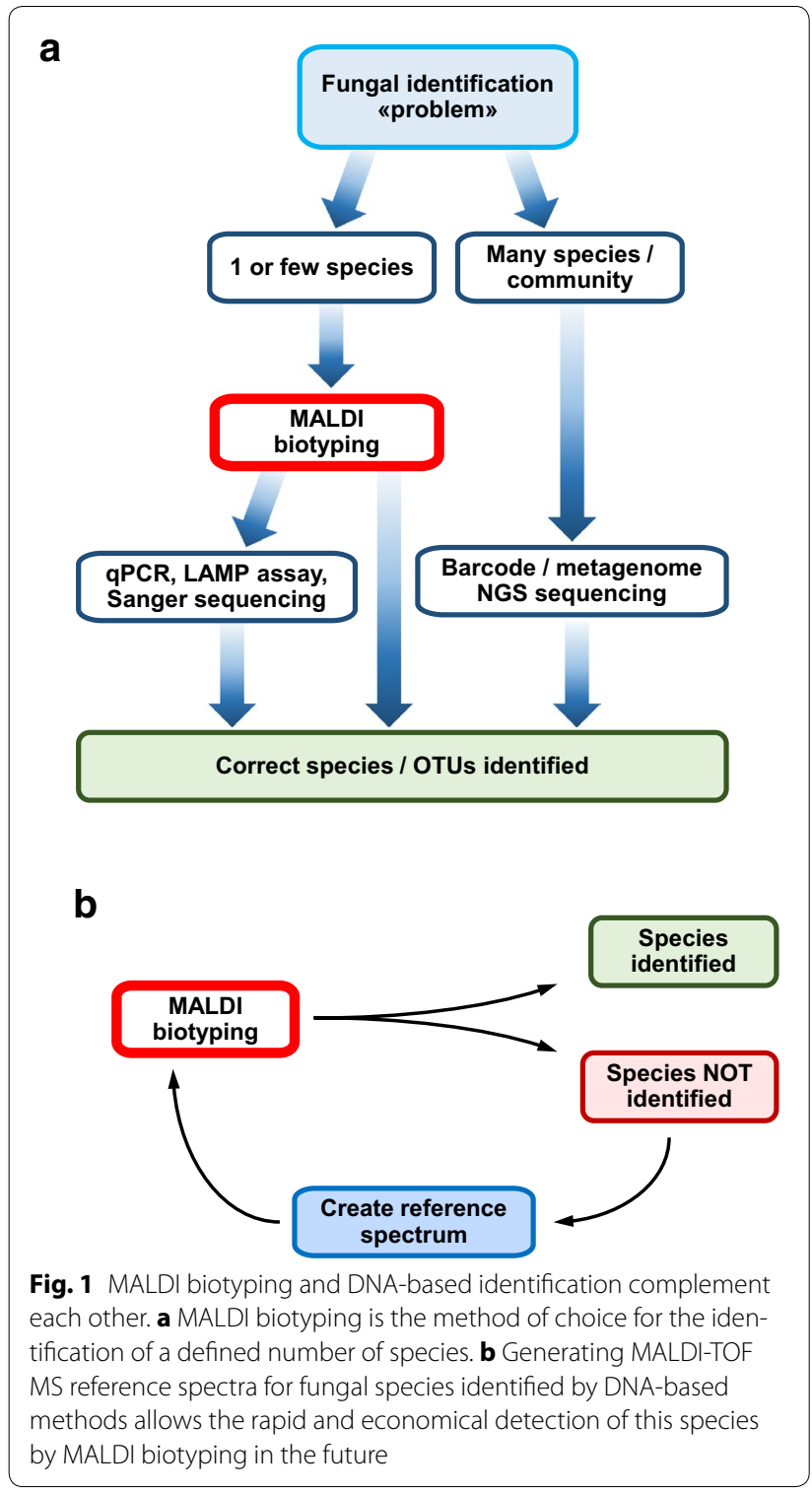

economical way. It is in this realm, where MALDI biotyping shines (Fig. 1a; Table 1).

In contrast to DNA sequencing-based approaches, MALDI-TOF MS uses whole cells or crude, acidic extracts, and mass spectra for the identification of individual species $[2,11]$. The simple sample preparation, short measurement times, easy preparation of reference spectra, and low costs per sample are important advantages of MALDI-TOF MS, as compared to specific, DNAbased assays that are often laborious to establish and usually require costly reagents (Table 1$)[1,12]$. MALDITOF MS is also highly flexible and can be combined with additional extraction or processing steps in order to identify specific biomarkers, metabolites, or biochemical functions. Because of these advantages, MALDI biotyping has become a standard in routine clinical diagnostics and MALDI-TOF MS devices have become readily accessible, also for researchers in other disciplines than clinical diagnostics $[4,13,14]$. This opens up new possibilities for functional hypothesis-driven research.

Unless it is the goal to identify entire microbial communities, MALDI-TOF MS is the method of choice for species identification, because it is fast, economical, and many common bacteria and an increasing number of fungi can be identified. In those cases where MALDITOF MS does not reveal the identity of a particular organism, classical Sanger sequencing or DNA-based assays (e.g., qPCR or LAMP assays) are used for identification (Fig. 1a; Table 1). Once the organism is identified based on such an assay, the generation of new MALDITOF MS reference spectra will allow identifying this species or isolate in the future (Fig. 1b). The iterative procedure comprises DNA-based identification and MALDITOF MS reference spectrum generation for each new organism continually increases the number of species that can be identified and thus the benefit of a particular MALDI-TOF MS system (comprises robust software, reliable algorithms, and databases). In particular in large culturomics projects, an integration of MALDI-TOF MS in the identification pipeline results in a comprehensive database of reference spectra that allows identifying a plethora of species and even challenges, or rather complements, DNA sequencing-based analyses of microbiomes $[15,16]$.

\section{Custom-made reference spectra improve MALDI-TOF MS-based identification}

DNA-based identification methods benefit from large, public, DNA sequence repositories, and many openly accessible or downloadable analysis tools. In contrast, MALDI-TOF MS reference spectra, as well as analysis tools, are usually proprietary, only commercially available, and heavily focused on medical applications. Even 
Table 1 MALDI-TOF- and DNA sequencing-based approaches complement each other

\begin{tabular}{|c|c|c|c|c|}
\hline & MALDI biotyping & qRT-PCR/lamp assay & Sanger sequencing & NGS sequencing \\
\hline Starting material & Crude extracts or whole cells & $\begin{array}{l}\text { DNA extract from mixed } \\
\text { sample }\end{array}$ & $\begin{array}{l}\text { DNA extract from pure } \\
\text { sample }\end{array}$ & $\begin{array}{l}\text { DNA extract from com- } \\
\text { munity }\end{array}$ \\
\hline Premises & Reference spectrum & Specific assay developed & $\begin{array}{l}\text { Clone or PCR product avail- } \\
\text { able }\end{array}$ & None/PCR product \\
\hline Equipment costs (machines) & High & Low-medium & High & High \\
\hline Cost per sample & Negligible & Low-medium & Medium & High \\
\hline Time for sample preparation & Short & Short-long & Long & Long \\
\hline Time for analysis & Short & Medium & Medium & Medium-long \\
\hline Data & $\begin{array}{l}\text { Mass spectrum of one } \\
\text { sample }\end{array}$ & $\begin{array}{l}\text { Detection of one DNA frag- } \\
\text { ment }\end{array}$ & $\begin{array}{l}\text { DNA sequence of } 400- \\
1000 \mathrm{bp}\end{array}$ & In total $50 \mathrm{Mbp}-1000 \mathrm{Gbp}$ \\
\hline $\begin{array}{l}\text { Number of species/strains } \\
\text { detected }\end{array}$ & Usually 1 per sample & 1 per assay & 1 per sample & Up to many thousands \\
\hline Cultivation step required & Usually yes & No & Usually yes & No \\
\hline
\end{tabular}

Properties and comparison of MALDI biotyping and DNA sequencing-based approaches (of barcodes/PCR products or genomic DNA) methods for the identification of fungi. References: [100, 101]

The advantages of each method are shown in italics

organisms commonly found in environmental, agricultural, or food samples are thus often not recognized by standard, commercial MALDI-TOF MS systems. In addition, MALDI-TOF MS spectra are not universal, such as a DNA sequence, but depend on the crude cell extract or the physiological state of the fungal cells that are applied onto the target plate and used for recording mass spectra. Consequently, the age and growth conditions of a microbial culture, as well as the settings of the ionizing laser, flight tube, and mass detector, can influence a MALDI biotyping experiment.

Many of these problems can be overcome by generating custom-made, specific MALDI-TOF MS reference spectra for the particular application in question [5]. Since these reference spectra are generated with the same MALD-TOF MS device, settings, and sample preparation as the experimental samples, the scores obtained with these references are usually higher as compared to generic reference databases [5, 17-19]. Custom-made reference spectra thus allow ample flexibility with respect to different sample preparation protocols and experimental set-ups in a particular lab or for specific applications. For example, reference spectra for different cell densities of a particular organism may allow an estimation of cell densities [20]. It is of course also possible to generate reference spectra for fungi grown on different agar plates, different physiological states, different extraction protocols, or directly applied bacterial or yeast cells (as opposed to crude extracts).

The integration of custom-made reference spectra in a commercial MALDI-TOF MS system is only the first step towards a truly open platform for MALDI-TOF MS-based species identification. Although it is easy to generate reference spectra, a comprehensive public repository of MALDI-TOF MS reference spectra is lacking. Such a resource would greatly facilitate the exchange of reference spectra between research groups and thus allow identifying microorganisms for which no reference spectra have been generated in a particular lab [21]. Until now, only few MALDI-TOF MS spectra databases for microbial identification are publicly available. The FoodBIMS database comprises reference mass spectra of food-borne bacteria [22] (http://bioinformatica.isa. cnr.it/Descr_Bact_Dbase.htm). SpectraBank is a freely accessible database that also comprises mainly bacterial reference spectra [23], and the free Spectra site hosts an extended database of MALDI-TOF MS reference spectra for bacteria and fungi (which is made available by the Public Health Agency of Sweden (Folkhälsomyndigheten): http://spectra.folkhalsomyndigheten.se/spectra/welcome.action).

In addition to MALDI-TOF MS data repositories, instrument- and provider-independent analysis tools for microbial biotyping using mass spectra are urgently needed. SPECLUST is an application to perform cluster analyses of MALDI-TOF MS spectra and was for example used to separate the bacterium Ralstonia solanacearum into different species [24, 25]. More recently, Starostin et al. [26] developed a tool to use geometric distances between MALDI-TOF MS spectra represented in a multi-dimensional space to distinguish closely related Bacillus strains. Mass-up is a comprehensive, open-source tool for the processing and analysis of MALDI-TOF MS data [27]. Besides classification, it has also biomarker discovery, principle component analysis, and clustering functions implemented and was, for example, used to fingerprint bacterial isolates or classify peritoneal dialysis patients by mass spectrometry-based 
profiling [28, 29]. For baseline correction, normalization, peak detection, and matching, it uses open-source packages such as MALDIquant [30] and MassSpec Wavelet [31], which are also available as separate $\mathrm{R}$ packages. Finally, BIOSPEAN (http://software.cr-hana.upol.cz/biospean/login.php) is a web-based application and database that was specifically developed for analyzing whole-cell MALDI-TOF MS data and includes peak picking, generation of MS databases, and data sharing among users [32].

The public deposition of MALDI-TOF MS spectra, together with information concerning culture conditions and experimental details is highly desirable and could largely expand the potential of MALDI-TOF MS for agricultural and food diagnostics, as well as ecological research. Standardized extraction buffers (an acidic extraction using formic acid and acetonitrile seems often used) and particularly matrix solutions (e.g., $\alpha$-cyano4-hydroxycinnamic acid, HCCA) would much improve comparability of results among different laboratories. However, since different types of cells and organisms require different extraction buffers and matrices for the best MALDI-TOF MS spectra, including this information in the reference spectra and in biotyping experiments seems necessary.

\section{Clinical MALDI-TOF MS applications benefit fungal diagnosis and research}

The low sample preparation costs and fast measurement time, in addition to its accuracy, are highly attractive properties of MALDI-TOF MS; in particular for clinical applications. MALDI biotyping of clinically relevant microorganisms is thus more advanced than of other microbes and new methods are first introduced and tested with clinical samples. Consequently, the majority of MALDI-TOF analyses of fungi so far have dealt with clinical isolates [33]. In particular, the rapid and economical identification of Candida species is an important medical application [34-39], but filamentous fungi present in clinical samples have been studied by MALDI biotyping as well [40-43]. Overall, MALDI-TOF MS is an accurate, reliable, and rapid method for the identification of human pathogenic fungi, and new applications for clinically relevant yeasts and filamentous fungi are continuously being developed [43-45]. A comparison of two commercially available systems, VITEK MS (bioMérieux) and MALDI Biotyper (Bruker Daltonics) with their associated databases, has shown similar identification efficiencies of clinically relevant yeasts for the two systems [46, 47], while other studies found differences between biotyping systems $[48,49]$. The identification power is improved by including in-house generated reference spectra in the databases $[17,43,46]$ (also see above). In addition, it was shown that the sample preparation method and quality of the database are crucial for accurate identification [38]. In general, identification rates for yeasts are above $90 \%$ and higher when using acidic extracts, as compared to direct transfer of whole cells $[38,50]$. In many cases, clinical diagnostics of human pathogenic bacteria and fungi drives the development of new MALDI biotyping approaches that will also benefit fungal diagnosis and research in other areas. It therefore seems worthwhile discussing new MALDI-TOF MS techniques that are mainly used in the clinical setting in order to highlight the potential and outline opportunities for MALDI-TOF MS of yeasts and filamentous fungi.

\section{Shortening the cultivation time for faster MALDI-TOF MS identification}

In clinical diagnostics, as in agricultural and food safety diagnostic, time-to-result and cost are the most important criteria for selecting analytical methods and may, in the most extreme situation, literally be a matter of life or death. The cultivation step, protein extraction, and pure cultures, in many cases required for a successful MALDI-TOF MS identification, may thus prevent this method from being used [51]. Therefore, efforts are undertaken and considerable progress has been made to address these shortcomings. For the diagnosis of bacterial pathogens responsible for bloodstream infections the mean incubation time to identify Gram-positive bacteria was $5.9 \mathrm{~h}$, which dropped to $3.1 \mathrm{~h}$ if a crude acidic extract was prepared [52]. In other studies, 97 to $69.5 \%$ of bacteria were correctly identified after a short incubation of positive blood cultures on solid media of only 3 to $5 \mathrm{~h}$ [53-56], which enabled identification on the same day as the positive blood sample was detected. By increasing the sample concentration (by reducing the sample spot size), creating reference spectra for different cell densities, and immunoaffinity enrichment of bacteria, it was possible to detect as few as 10 to 100 bacterial cells after a blood culture time of only $4 \mathrm{~h}$ [20]. These examples illustrate the vastly shortened time-to-result of clinical MALDI-TOF MS applications: the duration of the cultivation step has been reduced to just a few hours and is thus in the same range as DNA amplification steps. In other studies of positive urine or blood samples, or of cerebrospinal fluid, the cultivation step was omitted entirely, and pathogenic bacteria and yeasts were directly identified [57-59].

\section{MALDI-TOF MS applications beyond species identification}

MALDI-TOF MS is not only used for taxonomic identification, but also able to draw functional conclusions about clinically relevant properties of a particular isolate [60]. Since MALDI-TOF MS is, in principle, able to identify any ionizable compound [61], it can detect antibiotic resistance (e.g., via the identification of specific proteins 
or degradation products of antibiotics), but has also been used to reveal recombinant proteins, plasmid insertions in bacteria, or other biomarkers and diagnostic peptides in bacteria [62-66].

Recently, MALDI-TOF MS has been employed to rapidly and simultaneously detect and identify the Alternaria mycotoxins alternariol, monomethyl ether, and tentoxin in cereal grains [67]. It may be promising adapting this method for the identification of mycotoxins in further food products in the near future. The identification of clinically relevant anaerobic bacteria has also greatly benefited from MALDI-TOF MS approaches. This slow growing and fastidious group of pathogens has been mainly diagnosed by biochemical tests, but MALDI-TOF MS approaches have successfully identified such anaerobic pathogens and could delineate antibiotic-resistant and antibiotic-susceptible strains within the same species [68-70]. In the case of pathogenic yeasts, the sibling species of the Cryptococcus gattii/Cryptococcus neoformans complex, which cannot be discriminated by routine biochemical techniques, have been distinguished by MALDI biotyping [71]. Similarly, MALDI-TOF MS could reliably separate closely related members of the genus Saccharomyces (S. arboricola, S. bayanus, S. cariocanus, S. cerevisiae, S. kudriavzevii, S. mikatae, S. paradoxus, and $S$. pastorianus) [72]. Finally, MALDI-TOF MS more rapidly identified reduced susceptibility to caspofungin or triazoles in Candida and Aspergillus species, as compared to classical determination of the minimum inhibitory concentration [39, 73, 74]. With yeast cells from positive blood cultures and prepared by using the Sepsityper kit (Bruker Daltonics), direct MALDI-TOF MS identified the Candida species in $62.5 \%$ of the samples and antifungals susceptibility results were obtained for $72.7 \%$ of the blood samples [35]. Alterations in protein profiles of fungi following the exposure to antifungal compounds could be similarly used to monitor fungicide resistance in agriculturally relevant species.

\section{Sample processing can broaden the use of MALDI biotyping}

As for the highly sensitive species identification, discussed above, sample processing (e.g., tryptic digestion, acidic/organic extraction, nano-liquid chromatography) can greatly increase the sensitivity and specificity of a MALDI-TOF MS method and thus enable subspecies identification $[66,75]$. A further possibility is the functional modification of the MALDI target plates themselves, which was for example performed with antibodies for direct immunoaffinity MALDI-TOF MS of haptoglobin or by dioxide coating in order to enrich phosphopeptides $[76,77]$. In order to increase the number of mass peaks that may be used as biomarkers or the sensitivity of a MALDI-TOF MS analysis, samples have been successfully treated with detergent, sonication, corona plasma discharge, or heat [78-80]. In another study, target bacteria were separated and enriched without prior cultivation by using magnetic nanobeads that were functionalized with specific antibodies [20]. A rapid sample pretreatment consisting of removal of interfering blood cells and centrifugation and washing steps, which can also be performed with a commercially available kit (Sepsityper), is crucial for obtaining high identification rates of microorganisms, including yeasts, directly in positive blood cultures [81, 82]. These examples highlight that sample pretreatments are promising tools that may also benefit applications in agricultural diagnostics.

\section{MALDI-TOF MS of polymicrobial samples and infected material}

A standard MALDI biotyping experiment requires pure cultures of the microbial species to be identified. However, the identification of microorganisms from mixed or complex samples derived, for example, from patients, the environment, or infected plant tissue or food by MALDI-TOF MS is an important goal. So far, only a few reports have demonstrated the identification of bacteria and microalgae in mixtures by using biomarkers or correlation coefficients [83-85]. These studies have shown that ion suppression can affect the detection of specific masses of one or the other microorganism and thus complicate species identification in mixed samples [83, 84, 86]. On the other hand, novel mass peaks only observed in the mixed sample were discovered and may serve as biomarkers for mixtures or contaminations [83, 86]. For samples that contain more than two organisms, species identification based on biomarkers that invariably indicate the presence of a particular species performed better than correlation-based methods [84].

\section{Fungal MALDI biotyping as a tool for agricultural diagnostics and research}

MALDI biotyping of yeasts and filamentous fungi is more difficult than bacterial identifications, because the former result in less mass peaks and fewer reference spectra are available $[4,5]$. In contrast to clinically relevant fungi, only a limited number of fungal plant pathogens, postharvest diseases, or food contaminants have been detected by MALDI biotyping. The non-medical applications of MALDI-TOF MS for fungal diagnostics and research that we are aware of are summarized in Table 2. These studies document that in particular the genera Fusarium, Trichoderma, and Saccharomyces are being used as models for the development of MALDITOF MS applications and for assessing the potential of this technology. In contrast to clinical studies, naturally 
Table 2 Overview of MALDI-TOF MS studies of agriculturally relevant fungi

\begin{tabular}{|c|c|c|}
\hline Samples/organisms & Highlights & Reference \\
\hline Alternaria & $\begin{array}{l}\text { Detection of the Alternaria mycotoxins alternariol, alternariol monomethyl ether, and tentoxin } \\
\text { by MALDI-TOF MS }\end{array}$ & Sivagnanam et al. [67] \\
\hline Alternaria & $\begin{array}{l}\text { Separation of A. dauci, A. porri, A. solani, and A. tomatophila into three clusters by molecular } \\
\text { analyses and MALDI-TOF MS }\end{array}$ & Brun et al. [102] \\
\hline Alternaria & $\begin{array}{l}\text { Identification of } 60 \text { isolates of } 12 \text { Alternaria species by intact cell MALDI-TOF MS with small } \\
\text { mycelium samples }\end{array}$ & Chowdappa et al. [103] \\
\hline Aspergillus & $\begin{array}{l}\text { Optimization of protein extraction for } 24 \text { Aspergillus species from as few as 10,000 spores and } \\
\text { identification of } 11 \text { proteins }\end{array}$ & Sulc et al. [104] \\
\hline Aspergillus & Identification of 12 Aspergillus strains by preparing crude extracts by bead beating & Hettick et al. [105] \\
\hline Aspergillus & Characterisation of A. ibericus strains by MALDI-TOF MS and comparison with related species & Kallow et al. [106] \\
\hline Aspergillus & $\begin{array}{l}\text { Analysis of several aflatoxigenic and non-aflatoxigenic strain belonging to four Aspergillus } \\
\text { species }\end{array}$ & Li et al. [107] \\
\hline Aureobasidium & Analysis of extracellular liamocins (mannitol oils) produced by A. pullulans & Price et al. [108] \\
\hline Aureobasidium & Determination of oil structures of different A. pullulans strains & Manitchotpisit et al. [109] \\
\hline $\begin{array}{l}\text { Beer spoilage microor- } \\
\text { ganisms }\end{array}$ & Detection and distinction of beer spoilage yeasts and bacteria from brewing yeasts & Turvey et al. [19] \\
\hline Bremia, Oidium & $\begin{array}{l}\text { Identification of ribosomal proteins and histones as markers for the biotyping of plant patho- } \\
\text { gens }\end{array}$ & Beinhauer et al. [97] \\
\hline Chalara & $\begin{array}{l}\text { In vitro and in vivo identification of C. fraxinea by secondary metabolites collected in methanol } \\
\text { extracts }\end{array}$ & Pham et al. [110] \\
\hline Clonostachys & Cluster analysis of MALDI-TOF MS data of 45 Clonostachys strains from different substrates & Abreu et al. [111] \\
\hline $\begin{array}{l}\text { Downy and powdery } \\
\text { mildews }\end{array}$ & $\begin{array}{l}\text { Identification of the obligate biotrophic mildew fungi Bremia lactucae and Oidium neolycoper- } \\
\text { sici, also from infected leaves }\end{array}$ & Chalupova et al. [96] \\
\hline Fusarium & $\begin{array}{l}\text { Identification and characterisation of F. verticillioides and fumonisins by MALDI-TOF MS and } \\
\text { MALDI-TOF MS/MS }\end{array}$ & Chang et al. [112] \\
\hline Fusarium & Differentiation of Fusarium subspecies based on spores collected and prepared from isolates & $\begin{array}{l}\text { Marchetti-Deschmann } \\
\text { et al. [113] }\end{array}$ \\
\hline Fusarium & $\begin{array}{l}\text { Optimisation of MALDI biotyping of three Fusarium species (16 isolates) and identification of } \\
\text { proteins following on-target tryptic digestion }\end{array}$ & Dong et al. [114] \\
\hline Fusarium & Optimized sample preparation for strongly colored Fusarium conidia & Dong et al. [115] \\
\hline Fusarium & Mixed volume spore preparation for five Fusarium species & Kemptner et al. [116] \\
\hline Fusarium & $\begin{array}{l}\text { Differentiation of Fusarium species with ferulic acid as the matrix and the dried-droplet tech- } \\
\text { nique }\end{array}$ & Kemptner et al. [117] \\
\hline Gibberella & Characterisation of G. zeae conidia by on-target trypsin digestion & Dong et al. [118] \\
\hline Metarhizium & Reference spectra for distinguishing 51 isolates of the $M$. anisopliae species complex & Lopes et al. [119] \\
\hline Monilinia & Identification of Monilinia brown rot fungi directly from infect fruits & Freimoser et al. [18] \\
\hline Monilinia & Identification distinction of four Monilinia species cultivated in vitro & Horka et al. [120] \\
\hline Penicillium & Discrimination of 12 Penicillium species based on crude extracts obtained by bead beating & Hettick et al. [121] \\
\hline Penicillium & Six Penicillium species directly detected on citrus and apple fruits & Chen et al. [122] \\
\hline Puccinia & $\begin{array}{l}\text { Identification of different species and pathotypes of } P \text {. triticina and } P \text {. graminis by intact spore } \\
\text { MALDI-TOF MS }\end{array}$ & Beinhauer et al. [123] \\
\hline $\begin{array}{l}\text { Rhizopus, Trichoderma, } \\
\text { Phanerochaete }\end{array}$ & $\begin{array}{l}\text { Comparison of sample preparation, matrices, and double-stick tape for collection of fungal } \\
\text { material }\end{array}$ & Valentine et al. [124] \\
\hline Saccharomyces & Fingerprinting of 33 Saccharomyces strains commonly used for wine fermentation & Usbeck et al. [88] \\
\hline Saccharomyces & $\begin{array}{l}\text { Comparison of SAPD-PCR (specifically amplified polymorphic DNA) and MALDI-TOF MS for } \\
\text { identifying related Saccharomyces species }\end{array}$ & Blattel et al. [72] \\
\hline Saccharomyces & Identification of yeasts involved in chichi fermentation & Vallejo et al. [98] \\
\hline Saccharomyces & $\begin{array}{l}\text { MALDI-TOF MS characterization of protein biomarkers desorbed from S. cerevisiae by formic } \\
\text { acid }\end{array}$ & Amiri-Eliasi et al. [125] \\
\hline Sepedonium & $\begin{array}{l}\text { Characterisation of mycoparasitic Sepedonium species and analysis of low-molecular weight } \\
\text { peptides }\end{array}$ & Neuhof et al. [126] \\
\hline Spoilage yeasts & $\begin{array}{l}\text { Optimization of MALDI-TOF MS assay for Saccharomyces, Wickerhamomyces and Debaryomyces } \\
\text { isolated from beverages }\end{array}$ & Usbeck et al. [87] \\
\hline Trichoderma & Analysis of 129 Trichoderma strains by MALDI-TOF MS as well as ITS and tef1 sequencing & De Respinis et al. [127] \\
\hline
\end{tabular}


Table 2 continued

\begin{tabular}{|c|c|c|}
\hline Samples/organisms & Highlights & Reference \\
\hline Trichoderma & Characterisation and clustering of Trichoderma strains, their peptaibiotics, and hydrophobins & Degenkolb et al. [128] \\
\hline Trichoderma & Detection of peptaibols in 28 Trichoderma species & Neuhof et al. [129] \\
\hline Trichoderma & Direct identification of hydrophobins in Trichoderma isolates by MALDI-TOF MS & Neuhof et al. [130] \\
\hline Trichoderma, Rhizoctonia & $\begin{array}{l}\text { Visualization of metabolites produced during the antagonistic interaction of } T \text {. atroviride and } R \text {. } \\
\text { solani }\end{array}$ & Holzlechner et al. [131] \\
\hline Verticillium & Identification of six pathogenic Verticillium isolates with a protocol involving sonication & Tao et al. [132] \\
\hline Wood decay fungi & $\begin{array}{l}\text { Differentiation of closely related indoor wood decay fungi by MALDI-TOF MS (Serpula lacry- } \\
\text { mans, S. himantioides, Coniophora puteana, C. marmorata, and Antrodia vaillantii, A. sinuosa) }\end{array}$ & Schmidt and Kallow [133] \\
\hline $\begin{array}{l}\text { Yeasts and filamentous } \\
\text { fungi }\end{array}$ & MALDI lipid phenotyping as an alternative method for characterizing and identifying fungi & Stübiger et al. [134] \\
\hline Yeasts & $\begin{array}{l}\text { Identification of food-borne yeasts ( } \geq 33 \text { species, } 96 \text { isolates) by MALDI-TOF MS and conven- } \\
\text { tional methods }\end{array}$ & Pavlovic et al. [99] \\
\hline
\end{tabular}

occurring yeasts have been rarely studied by MALDITOF MS, except in the context of fermentations, for example, during winemaking and brewing [19, 72, 87, 88]. In general, the large majority of (non-clinical) fungal MALDI-TOF MS studies were directed towards phytopathogens (e.g., Aspergillus, Fusarium, Monilinia, Penicillium, Puccinia, mildews) or potential biocontrol strains (e.g., Trichoderma, Metarhizium). MALDI biotyping tools for other important soilborne or phyllosphere plant pathogens have not been established. Examples include Armillaria and Thielaviopsis, genera of worldwide root pathogens that attack hundreds of plant species $[89,90]$ or important oomycete pathogens such as Pythium, Plasmodiophora, or Phytophthora [91]. Also in the phyllosphere, pathogens such as Venturia inaequalis, the causative agent of apple scab [92], the apple blotch fungus Diplocarpon mali (Marssonina coronaria) [93, 94], and many others may be identified by MALDI biotyping and thus facilitate monitoring and studying these diseases. It is also worthwhile realizing that MALDI-TOF MS methods for identifying the majority of the fungal diseases recommended by the European and Mediterranean Plant Protection Organisation (EPPO) to be regulated as quarantine pests (List A1: https://www.eppo.int/ QUARANTINE/listA1.htm, List A2: https://www.eppo. int/QUARANTINE/listA2.htm) do not exist. The lack of MALDI-TOF MS protocols for such a wide range of economically important plant pathogens is surprising and highlights avenues for future research.

As in clinical diagnostics, the need to identify fungi often goes along with the goal to identify a particular organism directly in the environment, infected plant tissue, or food, which can harbor complex microbial communities and potentially host tissue. Examples of in situ identifications of microorganisms by MALDI-TOF MS include plant invasive Rhizobia [95], obligate biotrophic fungal pathogens $[96,97]$, or Monilinia brown rot fungi
[18]. In food science, MALDI biotyping has been mainly used for the identification of food-borne yeasts, which were pre-cultivated prior to MALDI-TOF MS analysis [87, 98, 99]. In own, unpublished work, we have developed an approach for identifying food quality and safetyrelevant fungi directly from contaminated apple juices by MALDI biotyping without pre-cultivation of the fungus. MALDI-TOF MS spectra of Byssochlamys fulva derived from both approaches-without and with pre-cultivation of the fungus in liquid medium-revealed the same protein profiles and allowed accurate species identification (Fig. 2). These studies and results document the potential of MALDI-TOF MS to identify fungal pathogens directly in infected tissue or food.

In particular for the diagnosis of plant pathogens, food contaminants, and spoilage organisms, biomarker-based identification will permit identifying key species in complex mixtures by MALDI-TOF MS. However, so far the MALDI-TOF MS-based identification of fungal mixtures has not yet been reported.

\section{Conclusions}

Although numerous fungi have been identified by MALDI-TOF MS already, this technology is far from being a standard tool for the identification of fungi and their functions. Overall, the examples highlighted here demonstrate that the potential of MALDI-TOF MS for clinical diagnostics, and diagnostic and research applications in general, is far from being exhausted. None of the recent methodological improvements (e.g., direct smear after short cultivation times, sample concentration, immunoaffinity enrichment, subspecies identification, functionalization of MALDI target plates, biomarker-based identification in polymicrobial samples) is inherently limited to clinical samples or only bacteria. Translating these improvements and developments to other areas of diagnostics (e.g., of plant pathogens or 


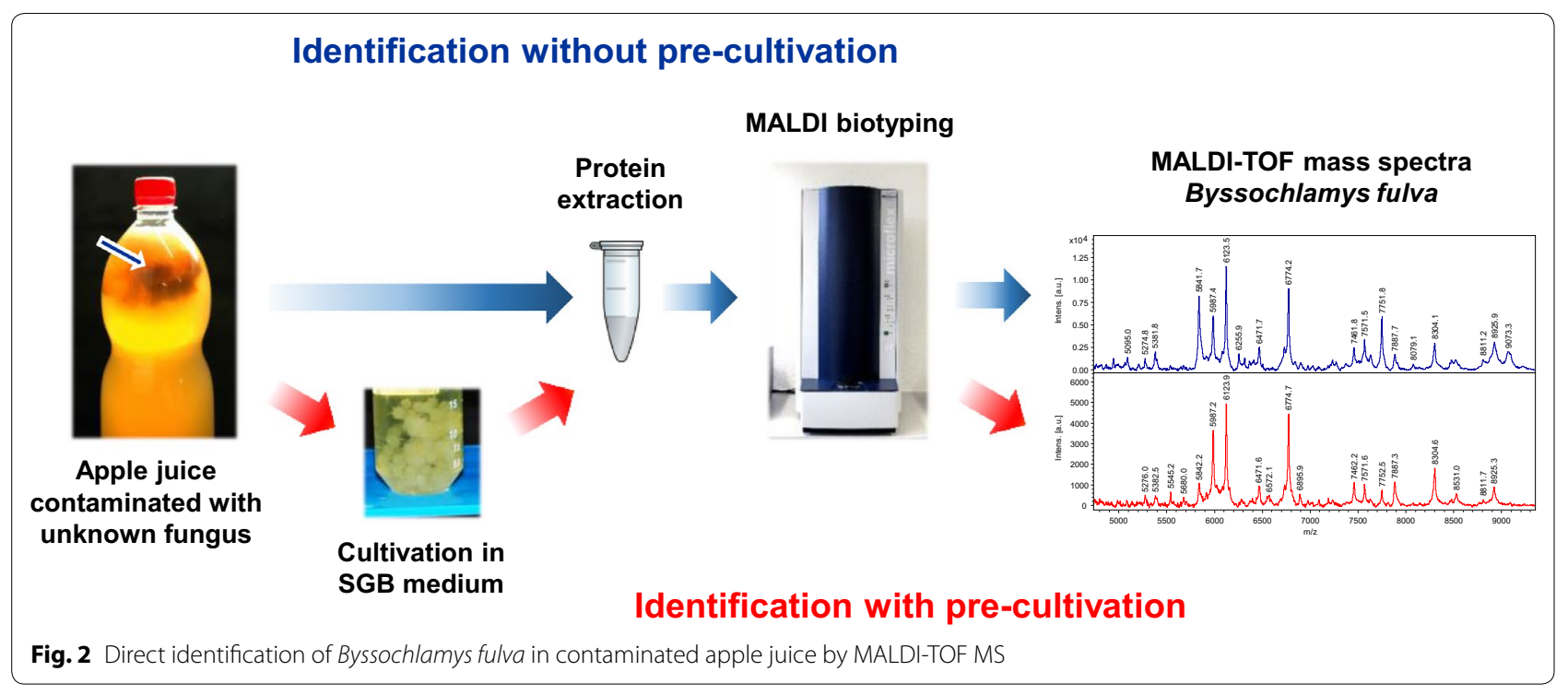

food spoilages) and to other microorganisms, such as filamentous fungi and yeasts, will thus enable experimental research in bacterial and fungal diagnostics, ecology, physiology, or pathology.

\section{Authors' contributions}

Both authors planned and wrote the manuscript together. Both authors read and approved the final manuscript.

\section{Author details}

${ }^{1}$ Research Group Microbiology of Plant Foods, Agroscope, Schloss 1 , 8820 Wädenswil, Switzerland. ${ }^{2}$ Research Division Plant Protection, Agroscope, Schloss 1, 8820 Wädenswil, Switzerland.

\section{Acknowledgements}

We are indebted to René Brunisholz (Functional Genomics Center Zurich, FGCZ) for valuable scientific discussions and help with MALDI-TOF MS analysis of Byssochlamys fulva.

\section{Competing interests}

The authors declare that they have no competing interests.

\section{Funding}

The research of both authors is funded by Agroscope.

\section{Publisher's Note}

Springer Nature remains neutral with regard to jurisdictional claims in published maps and institutional affiliations.

Received: 2 November 2016 Accepted: 20 February 2017 Published online: 09 May 2017

\section{References}

1. Singhal N, Kumar M, Kanaujia PK, Virdi JS. MALDI-TOF mass spectrometry: an emerging technology for microbial identification and diagnosis. Front Microbiol. 2015;6:791.

2. Patel R. MALDI-TOF MS for the diagnosis of infectious diseases. Clin Chem. 2015;61(1):100-11.
3. Posteraro B, Efremov L, Leoncini E, Amore R, Posteraro P, Ricciardi W, et al. Are the conventional commercial yeast identification methods still helpful in the era of new clinical microbiology diagnostics? A metaanalysis of their accuracy. J Clin Microbiol. 2015;53(8):2439-50.

4. Chalupova J, Raus M, Sedlarova M, Sebela M. Identification of fungal microorganisms by MALDI-TOF mass spectrometry. Biotechnol Adv. 2014:32(1):230-41.

5. Rahi P, Prakash O, Shouche YS. Matrix-assisted laser desorption/ionization time-of-flight mass-spectrometry (MALDI-TOF MS) based microbial identifications: challenges and scopes for microbial ecologists. Front Microbiol. 2016;7:1359.

6. Schoch CL, Seifert KA, Huhndorf S, Robert V, Spouge JL, Levesque CA, et al. Nuclear ribosomal internal transcribed spacer (ITS) region as a universal DNA barcode marker for Fungi. P Natl Acad Sci USA. 2012;109(16):6241-6.

7. Franzosa EA, Hsu T, Sirota-Madi A, Shafquat A, Abu-Ali G, Morgan XC, et al. Sequencing and beyond: integrating molecular 'omics' for microbial community profiling. Nat Rev Microbiol. 2015;13(6):360-72.

8. Shendure J, Ji H. Next-generation DNA sequencing. Nat Biotechnol. 2008;26(10):1135-45.

9. Niedringhaus TP, Milanova D, Kerby MB, Snyder MP, Barron AE. Landscape of next-generation sequencing technologies. Anal Chem. 2011;83(12):4327-41.

10. Muir P, Li S, Lou S, Wang D, Spakowicz DJ, Salichos L, et al. The real cost of sequencing: scaling computation to keep pace with data generation. Genome Biol. 2016;17:53.

11. Drissner D, Gekenidis MT, Schlapbach R, Brunisholz R. When time-toresult matters: identification of microbes based on MALDI-TOF protein and peptide profiling. Chimia. 2014;68(6):453.

12. Deng J, Fu L, Wang R, Yu N, Ding X, Jiang L, et al. Comparison of MALDITOF MS, gene sequencing and the Vitek 2 for identification of seventythree clinical isolates of enteropathogens. J Thorac Dis. 2014;6(5):539-44.

13. Wenning M, Breitenwieser F, Konrad R, Huber I, Busch U, Scherer S. Identification and differentiation of food-related bacteria: a comparison of FTIR spectroscopy and MALDI-TOF mass spectrometry. J Microbiol Methods. 2014;103:44-52.

14. Quintela-Baluja M, Böhme K, Fernandez-No IC, Morandi S, Alnakip ME, Caamano-Antelo S, et al. Characterization of different food-isolated Enterococcus strains by MALDI-TOF mass fingerprinting. Electrophoresis. 2013;34(15):2240-50.

15. Lagier JC, Armougom F, Million M, Hugon P, Pagnier I, Robert C, et al. Microbial culturomics: paradigm shift in the human gut microbiome study. Clin Microbiol Infect. 2012;18(12):1185-93. 
16. Lagier JC, Hugon P, Khelaifia S, Fournier PE, La Scola B, Raoult D. The rebirth of culture in microbiology through the example of culturomics to study human gut microbiota. Clin Microbiol Rev. 2015;28(1):237-64.

17. Becker PT, de Bel A, Martiny D, Ranque S, Piarroux R, Cassagne C, et al. Identification of filamentous fungi isolates by MALDI-TOF mass spectrometry: clinical evaluation of an extended reference spectra library. Med Mycol. 2014;52(8):826-34.

18. Freimoser FM, Hilber-Bodmer M, Brunisholz R, Drissner D. Direct identification of Monilinia brown rot fungi on infected fruits by matrix-assisted laser desorption/ionization (MALDI) mass spectrometry. Chem Biol Technol Agricult. 2016;3:7.

19. Turvey ME, Weiland F, Meneses J, Sterenberg N, Hoffmann P. Identification of beer spoilage microorganisms using the MALDI Biotyper platform. Appl Microbiol Biotechnol. 2016;100(6):2761-73.

20. Zhu Y, Qiao L, Prudent M, Bondarenko A, Gasilova N, Möller SB, et al. Sensitive and fast identification of bacteria in blood samples by immunoaffinity mass spectrometry for quick BSI diagnosis. Chem Sci. 2016;7(5):2987-95.

21. Del Chierico F, Petrucca A, Vernocchi P, Bracaglia G, Fiscarelli E, Bernaschi $P$, et al. Proteomics boosts translational and clinical microbiology. J Proteomics. 2014;97:69-87.

22. Mazzeo MF, Sorrentino A, Gaita M, Cacace G, Di Stasio M, Facchiano A, et al. Matrix-assisted laser desorption ionization-time of flight mass spectrometry for the discrimination of food-borne microorganisms. Appl Environ Microbiol. 2006;72(2):1180-9.

23. Böhme K, Fernandez-No IC, Barros-Velazquez J, Gallardo JM, Canas B, Calo-Mata P. SpectraBank: an open access tool for rapid microbial identification by MALDI-TOF MS fingerprinting. Electrophoresis. 2012;33(14):2138-42.

24. Prior P, Ailloud F, Dalsing BL, Remenant B, Sanchez B, Allen C. Genomic and proteomic evidence supporting the division of the plant pathogen Ralstonia solanacearum into three species. BMC Genom. 2016;17:90.

25. Alm R, Johansson P, Hjerno K, Emanuelsson C, Ringner M, Hakkinen J. Detection and identification of protein isoforms using cluster analysis of MALDI-MS mass spectra. J Proteome Res. 2006;5(4):785-92.

26. Starostin KV, Demidov EA, Bryanskaya AV, Efimov VM, Rozanov AS, Peltek SE. Identification of Bacillus strains by MALDI TOF MS using geometric approach. Sci Rep. 2015;5:16989.

27. Lopez-Fernandez H, Santos HM, Capelo JL, Fdez-Riverola F, Glez-Pena D, Reboiro-Jato M. Mass-Up: an all-in-one open software application for MALDI-TOF mass spectrometry knowledge discovery. BMC Bioinformatics. 2015;16:318.

28. Santos T, Capelo JL, Santos HM, Oliveira I, Marinho C, Goncalves A, et al. Use of MALDI-TOF mass spectrometry fingerprinting to characterize Enterococcus spp. and Escherichia coli isolates. J Proteomics. 2015;127(Pt B):321-31.

29. Araujo JE, Jorge S, Magrico R, e Costa T, Ramos A, Reboiro-Jato M, et al. Classifying patients in peritoneal dialysis by mass spectrometry-based profiling. Talanta. 2016;152:364-70

30. Gibb S, Strimmer K. MALDlquant: a versatile R package for the analysis of mass spectrometry data. Bioinformatics. 2012;28(17):2270-1.

31. Du P, Kibbe WA, Lin SM. Improved peak detection in mass spectrum by incorporating continuous wavelet transform-based pattern matching. Bioinformatics. 2006;22(17):2059-65.

32. Raus M, Sebela M. BIOSPEAN: a freeware tool for processing spectra from MALDI intact cell/spore mass spectrometry. J Proteomics Bioinf. 2013;6(12):283-7.

33. Rizzato C, Lombardi L, Zoppo M, Lupetti A. Pushing the limits of MALDITOF mass spectrometry: beyond fungal species identification. J Fungi. 2015; 1:367-83.

34. De Carolis E, Vella A, Vaccaro L, Torelli R, Posteraro P, Ricciardi W, et al. Development and validation of an in-house database for matrixassisted laser desorption ionization-time of flight mass spectrometrybased yeast identification using a fast protein extraction procedure. J Clin Microbiol. 2014;52(5):1453-8.

35. Idelevich EA, Grunewald CM, Wüllenweber J, Becker K. Rapid identification and susceptibility testing of Candida spp. from positive blood cultures by combination of direct MALDI-TOF mass spectrometry and direct inoculation of Vitek 2. PLoS ONE. 2014;9(12):e114834.
36. Spanu T, Posteraro B, Fiori B, D'Inzeo T, Campoli S, Ruggeri A, et al. Direct MALDI-TOF mass spectrometry assay of blood culture broths for rapid identification of Candida species causing bloodstream infections: an observational study in two large microbiology laboratories. J Clin Microbiol. 2012;50(1):176-9.

37. Marklein G, Josten M, Klanke U, Müller E, Horre R, Maier T, et al. Matrixassisted laser desorption ionization-time of flight mass spectrometry for fast and reliable identification of clinical yeast isolates. J Clin Microbiol. 2009;47(9):2912-7.

38. Vlek A, Kolecka A, Khayhan K, Theelen B, Groenewald M, Boel E, et al. Interlaboratory comparison of sample preparation methods, database expansions, and cutoff values for identification of yeasts by matrixassisted laser desorption ionization-time of flight mass spectrometry using a yeast test panel. J Clin Microbiol. 2014;52(8):3023-9.

39. Saracli MA, Fothergill AW, Sutton DA, Wiederhold NP. Detection of triazole resistance among Candida species by matrix-assisted laser desorption/ionization-time of flight mass spectrometry (MALDI-TOF MS). Med Mycol. 2015;53(7):736-42.

40. Welham KJ, Domin MA, Johnson K, Jones L, Ashton DS. Characterization of fungal spores by laser desorption/ionization time-of-flight mass spectrometry. Rapid Commun Mass Spectrom. 2000;14(5):307-10.

41. De Carolis E, Posteraro B, Lass-Florl C, Vella A, Florio AR, Torelli R, et al. Species identification of Aspergillus, Fusarium and Mucorales with direct surface analysis by matrix-assisted laser desorption ionization time-of-flight mass spectrometry. Clin Microbiol Infect. 2012;18(5):475-84.

42. Nenoff P, Erhard M, Simon JC, Muylowa GK, Herrmann J, Rataj W, et al. MALDI-TOF mass spectrometry - a rapid method for the identification of dermatophyte species. Med Mycol. 2013;51(1):17-24.

43. L'Ollivier C, Ranque S. MALDI-TOF-based dermatophyte identification. Mycopathologia. 2017;182(1-2):183-92.

44. Ling H, Yuan Z, Shen J, Wang Z, Xu Y. Accuracy of matrix-assisted laser desorption ionization-time of flight mass spectrometry for identification of clinical pathogenic fungi: a meta-analysis. J Clin Microbiol. 2014;52(7):2573-82.

45. Posteraro B, De Carolis E, Vella A, Sanguinetti M. MALDI-TOF mass spectrometry in the clinical mycology laboratory: identification of fungi and beyond. Expert Rev Proteomics. 2013;10(2):151-64.

46. Mancini N, De Carolis E, Infurnari L, Vella A, Clementi N, Vaccaro L, et al. Comparative evaluation of the Bruker Biotyper and Vitek MS matrixassisted laser desorption ionization-time of flight (MALDI-TOF) mass spectrometry systems for identification of yeasts of medical importance. J Clin Microbiol. 2013;51(7):2453-7.

47. Jamal WY, Ahmad S, Khan ZU, Rotimi VO. Comparative evaluation of two matrix-assisted laser desorption/ionization time-of-flight mass spectrometry (MALDI-TOF MS) systems for the identification of clinically significant yeasts. Int J Infect Dis. 2014;26:167-70.

48. Wang H, Fan YY, Kudinha T, Xu ZP, Xiao M, Zhang L, et al. A comprehensive evaluation of the Bruker Biotyper MS and Vitek MS matrix-assisted laser desorption ionization-time of flight mass spectrometry systems for identification of yeasts, part of the National China Hospital Invasive Fungal Surveillance Net (CHIF-NET) study, 2012 to 2013. J Clin Microbiol. 2016;54(5):1376-80.

49. Cheng JW, Yu SY, Xiao M, Wang H, Kudinha T, Kong F, et al. Identification and antifungal susceptibility profile of Candida guilliermondii and Candida fermentati from a multicenter study in China. J Clin Microbiol. 2016;54(8):2187-9.

50. McTaggart LR, Lei E, Richardson SE, Hoang L, Fothergill A, Zhang SX. Rapid identification of Cryptococcus neoformans and Cryptococcus gattii by matrix-assisted laser desorption ionization-time of flight mass spectrometry. J Clin Microbiol. 2011;49(8):3050-3.

51. van Belkum A, Chatellier S, Girard V, Pincus D, Deol P, Dunne WM Jr. Progress in proteomics for clinical microbiology: MALDI-TOF MS for microbial species identification and more. Expert Rev Proteomics. 2015;12(6):595-605

52. Idelevich EA, Schüle I, Grünastel B, Wüllenweber J, Peters G, Becker K. Rapid identification of microorganisms from positive blood cultures by MALDI-TOF mass spectrometry subsequent to very short-term incubation on solid medium. Clin Microbiol Infect. 2014;20(10):1001-6. 
53. Chen Y, Porter V, Mubareka S, Kotowich L, Simor AE. Rapid identification of bacteria directly from positive blood cultures by use of a serum separator tube, smudge plate preparation, and matrix-assisted laser desorption ionization-time of flight mass spectrometry. J Clin Microbiol. 2015;53(10):3349-52.

54. Verroken A, Defourny L, Lechgar L, Magnette A, Delmee M, Glupczynski Y. Reducing time to identification of positive blood cultures with MALDI-TOF MS analysis after a 5-h subculture. Eur J Clin Microbiol Infect Dis. 2015;34(2):405-13.

55. Zabbe JB, Zanardo L, Megraud F, Bessede E. MALDI-TOF mass spectrometry for early identification of bacteria grown in blood culture bottles. J Microbiol Methods. 2015;115:45-6.

56. Kohlmann R, Hoffmann A, Geis G, Gatermann S. MALDI-TOF mass spectrometry following short incubation on a solid medium is a valuable tool for rapid pathogen identification from positive blood cultures. Int J Med Microbiol. 2015;305(4-5):469-79.

57. Ferreira L, Sanchez-Juanes F, Munoz-Bellido JL, Gonzalez-Buitrago JM. Rapid method for direct identification of bacteria in urine and blood culture samples by matrix-assisted laser desorption ionization timeof-flight mass spectrometry: intact cell vs. extraction method. Clin Microbiol Infect. 2011;17(7):1007-12.

58. Ferreira L, Sanchez-Juanes F, Porras-Guerra I, Garcia-Garcia MI, GarciaSanchez JE, Gonzalez-Buitrago JM, et al. Microorganisms direct identification from blood culture by matrix-assisted laser desorption/ ionization time-of-flight mass spectrometry. Clin Microbiol Infect. 2011:17(4):546-51.

59. Clark AE, Kaleta EJ, Arora A, Wolk DM. Matrix-assisted laser desorption ionization-time of flight mass spectrometry: a fundamental shift in the routine practice of clinical microbiology. Clin Microbiol Rev. 2013;26(3):547-603

60. Doern CD, Butler-Wu SM. Emerging and future applications of matrixassisted laser desorption ionization time-of-flight (MALDI-TOF) mass spectrometry in the clinical microbiology laboratory: a report of the association for molecular pathology. J Mol Diagn. 2016;18(6):789-802.

61. Crutchfield CA, Thomas SN, Sokoll LJ, Chan DW. Advances in mass spectrometry-based clinical biomarker discovery. Clin Proteomics. 2016:13:1.

62. Niyompanich S, Srisanga K, Jaresitthikunchai J, Roytrakul S, Tungpradabkul S. Utilization of whole-cell MALDI-TOF mass spectrometry to differentiate Burkholderia pseudomallei wild-type and constructed mutants. PLOS ONE. 2015;10(12):e0144128.

63. Penny C, Grothendick B, Zhang L, Borror CM, Barbano D, Cornelius AJ, et al. A designed experiments approach to optimizing MALDI-TOF MS spectrum processing parameters enhances detection of antibiotic resistance in Campylobacter jejuni. Front Microbiol. 2016;7:818.

64. Schaumann R, Knoop N, Genzel GH, Losensky K, Rosenkranz C, Stingu CS, et al. A step towards the discrimination of beta-lactamaseproducing clinical isolates of Enterobacteriaceae and Pseudomonas aeruginosa by MALDI-TOF mass spectrometry. Med Sci Monit. 2012;18(9):MT71-7.

65. Pfrunder S, Grossmann J, Hunziker P, Brunisholz R, Gekenidis MT, Drissner D. Bacillus cereus group-type strain-specific diagnostic peptides. J Proteome Res. 2016;15(9):3098-107.

66. Cho YT, Su H, Wu WJ, Wu DC, Hou MF, Kuo CH, et al. Biomarker characterization by MALDI-TOF/MS. Adv Clin Chem. 2015;69:209-54.

67. Sivagnanam K, Komatsu E, Rampitsch C, Perreault H, Gräfenhan T. Rapid screening of Alternaria mycotoxins using MALDI-TOF mass spectrometry. J Sci Food Agric. 2017;97(1):357-61.

68. Kostrzewa M, Nagy E. How MALDI-TOF mass spectrometry can aid diagnosis of hard-to-identify pathogenic bacteria. Expert Rev Mol Diagn. 2016;16(5):509-11.

69. Nagy E. Matrix-assisted laser desorption/ionization time-of-flight mass spectrometry: a new possibility for the identification and typing of anaerobic bacteria. Future Microbiol. 2014;9(2):217-33.

70. Barreau M, Pagnier I, La Scola B. Improving the identification of anaerobes in the clinical microbiology laboratory through MALDI-TOF mass spectrometry. Anaerobe. 2013;22:123-5.

71. Hagen F, Khayhan K, Theelen B, Kolecka A, Polacheck I, Sionov E, et al. Recognition of seven species in the Cryptococcus gattii/Cryptococcus neoformans species complex. Fungal Genet Biol. 2015;78:16-48.
72. Blattel V, Petri A, Rabenstein A, Kuever J, Konig H. Differentiation of species of the genus Saccharomyces using biomolecular fingerprinting methods. Appl Microbiol Biotechnol. 2013;97(10):4597-606.

73. De Carolis E, Vella A, Florio AR, Posteraro P, Perlin DS, Sanguinetti M, et al. Use of matrix-assisted laser desorption ionization-time of flight mass spectrometry for caspofungin susceptibility testing of Candida and Aspergillus species. J Clin Microbiol. 2012;50(7):2479-83.

74. Vella A, De Carolis E, Vaccaro L, Posteraro P, Perlin DS, Kostrzewa M, et al. Rapid antifungal susceptibility testing by matrix-assisted laser desorption ionization-time of flight mass spectrometry analysis. J Clin Microbiol. 2013;51(9):2964-9.

75. Gekenidis MT, Studer P, Wüthrich S, Brunisholz R, Drissner D. Beyond the matrix-assisted laser desorption ionization (MALDI) biotyping workflow: in search of microorganism-specific tryptic peptides enabling discrimination of subspecies. Appl Environ Microb. 2014;80(14):4234-41.

76. Pompach P, Novakova J, Kavan D, Benada O, Ruzicka V, Volny M, et al. Planar functionalized surfaces for direct immunoaffinity desorption/ ionization mass spectrometry. Clin Chem. 2016;62(1):270-8.

77. Krasny L, Pompach P, Strohalm M, Obsilova V, Strnadova M, Novak P, et al. In-situ enrichment of phosphopeptides on MALDI plates modified by ambient ion landing. J Mass Spectrom. 2012;47(10):1294-302.

78. Horneffer V, Haverkamp J, Janssen HG, ter Steeg PF, Notz R. MALDI-TOFMS analysis of bacterial spores: wet heat-treatment as a new releasing technique for biomarkers and the influence of different experimental parameters and microbiological handling. J Am Soc Mass Spectrom. 2004;15(10):1444-54

79. Ryzhov V, Hathout Y, Fenselau C. Rapid characterization of spores of Bacillus cereus group bacteria by matrix-assisted laser desorptionionization time-of-flight mass spectrometry. Appl Environ Microbiol. 2000;66(9):3828-34

80. Nilsson CL. Fingerprinting of Helicobacter pylori strains by matrixassisted laser desorption/ionization mass spectrometric analysis. Rapid Commun Mass Spectrom. 1999;13(11):1067-71.

81. Yan Y, He Y, Maier T, Quinn C, Shi G, Li H, et al. Improved identification of yeast species directly from positive blood culture media by combining Sepsityper specimen processing and Microflex analysis with the matrix-assisted laser desorption ionization Biotyper system. J Clin Microbiol. 2011;49(7):2528-32.

82. Bidart M, Bonnet I, Hennebique A, Kherraf ZE, Pelloux H, Berger F, et al. An in-house assay is superior to Sepsityper for direct matrix-assisted laser desorption ionization-time of flight (MALDI-TOF) mass spectrometry identification of yeast species in blood cultures. J Clin Microbiol. 2015;53(5):1761-4.

83. Barbano D, Diaz R, Zhang L, Sandrin T, Gerken H, Dempster T. Rapid characterization of microalgae and microalgae mixtures using matrixassisted laser desorption ionization time-of-flight mass spectrometry (MALDI-TOF MS). PLOS ONE. 2015;10(8):e0135337.

84. Zhang L, Smart S, Sandrin TR. Biomarker- and similarity coefficientbased approaches to bacterial mixture characterization using matrixassisted laser desorption ionization time-of-flight mass spectrometry (MALDI-TOF MS). Sci Rep. 2015;5:15834.

85. Mahe P, Arsac M, Chatellier S, Monnin V, Perrot N, Mailler S, et al. Automatic identification of mixed bacterial species fingerprints in a MALDI-TOF mass-spectrum. Bioinformatics. 2014;30(9):1280-6.

86. Holland RD, Wilkes JG, Cooper WM, Alusta P, Williams A, Pearce B, et al. Thymol treatment of bacteria prior to matrix-assisted laser desorption/ ionization time-of-flight mass spectrometric analysis aids in identifying certain bacteria at the subspecies level. Rapid Commun Mass Spectrom. 2014;28(23):2617-26.

87. Usbeck JC, Kern CC, Vogel RF, Behr J. Optimization of experimental and modelling parameters for the differentiation of beverage spoiling yeasts by matrix-assisted-laser-desorption/ionization-time-of-flight mass spectrometry (MALDI-TOF MS) in response to varying growth conditions. Food Microbiol. 2013;36(2):379-87.

88. Usbeck JC, Wilde C, Bertrand D, Behr J, Vogel RF. Wine yeast typing by MALDI-TOF MS. Appl Microbiol Biotechnol. 2014;98(8):3737-52.

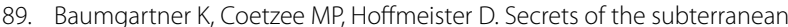
pathosystem of Armillaria. Mol Plant Pathol. 2011;12(6):515-34.

90. Hood ME, Shew HD. Reassessment of the role of saprophytic activity in the ecology of Thielaviopsis basicola. Phytopathology. 1997:87(12):1214-9. 
91. Fry WE, Grünwald NJ. Introduction to oomycetes. Plant Health Instr. 2010;1207:01.

92. Bowen JK, Mesarich CH, Bus VG, Beresford RM, Plummer KM, Templeton MD. Venturia inaequalis: the causal agent of apple scab. Mol Plant Pathol. 2011;12(2):105-22.

93. Harada Y, Sawamura K, Konno K. Diplocarpon mali sp. nov., the perfect state of apple blotch fungus Marssonina coronaria. Ann Phytopathol Soc Jpn. 1974;40(5):412-8.

94. Lee DH, Back CG, Win NK, Choi KH, Kim KM, Kang IK, et al. Biological characterization of Marssonina coronaria associated with apple blotch disease. Mycobiology. 2011;39(3):200-5.

95. Ziegler D, Mariotti A, Pflüger V, Saad M, Vogel G, Tonolla M, et al. In situ identification of plant-invasive bacteria with MALDI-TOF mass spectrometry. PLoS ONE. 2012;7(5):e37189.

96. Chalupova J, Sedlarova M, Helmel M, Rehulka P, Marchetti-Deschmann $\mathrm{M}$, Allmaier $\mathrm{G}$, et al. MALDI-based intact spore mass spectrometry of downy and powdery mildews. J Mass Spectrom. 2012;47(8):978-86.

97. Beinhauer J, Lenobel R, Loginov D, Chamrad I, Rehulka P, Sedlarova M, et al. Identification of Bremia lactucae and Oidium neolycopersici proteins extracted for intact spore MALDI mass spectrometric biotyping. Electrophoresis. 2016;37:2940-52.

98. Vallejo JA, Miranda P, Flores-Felix JD, Sanchez-Juanes F, Ageitos JM, Gonzalez-Buitrago JM, et al. Atypical yeasts identified as Saccharomyces cerevisiae by MALDI-TOF MS and gene sequencing are the main responsible of fermentation of chicha, a traditional beverage from Peru. Syst Appl Microbiol. 2013;36(8):560-4.

99. Pavlovic M, Mewes A, Maggipinto M, Schmidt W, Messelhäusser U, Balsliemke J, et al. MALDI-TOF MS based identification of food-borne yeast isolates. J Microbiol Methods. 2014;106:123-8.

100. Knief C. Analysis of plant microbe interactions in the era of next generation sequencing technologies. Front Plant Sci. 2014;5:216.

101. Rhoads A, Au KF. PacBio sequencing and its applications. Genom Proteom Bioinform. 2015;13(5):278-89.

102. Brun S, Madrid H, Gerrits Van Den Ende B, Andersen B, Marinach-Patrice C, Mazier D, et al. Multilocus phylogeny and MALDI-TOF analysis of the plant pathogenic species Alternaria dauci and relatives. Fungal Biol. 2013;117(1):32-40.

103. Chowdappa P, Lakshmi MJ, Madhura S. Matrix assisted laser desorption ionization-time of flight (MALDI-TOF) mass spectrometry for identification of plant pathogenic Alternaria species. Phytoparasitica. 2013:41(2):169-79.

104. Sulc M, Peslova K, Zabka M, Hajduch M, Havlicek V. Biomarkers of Aspergillus spores: strain typing and protein identification. Int J Mass Spectrom. 2009;280:162-8.

105. Hettick JM, Green BJ, Buskirk AD, Kashon ML, Slaven JE, Janotka E, et al. Discrimination of Aspergillus isolates at the species and strain level by matrix-assisted laser desorption/ionization time-of-flight mass spectrometry fingerprinting. Anal Biochem. 2008;380(2):276-81.

106. Kallow W, Santos I, Erhard M, Serra R, Venancio A, Lima N, editors. Aspergillus ibericus: a new species of section Nigri characterised by MALDITOF MS. 8th International mycological congress. Cairns: MEDIMOND; 2006.

107. Li TY, Liu BH, Chen YC. Characterization of Aspergillus spores by matrixassisted laser desorption/ionization time-of-flight mass spectrometry. Rapid Commun Mass Spectrom. 2000;14(24):2393-400.

108. Price NP, Manitchotpisit P, Vermillion KE, Bowman MJ, Leathers TD. Structural characterization of novel extracellular liamocins (mannitol oils) produced by Aureobasidium pullulans strain NRRL 50380. Carbohydr Res. 2013;370:24-32.

109. Manitchotpisit P, Price NP, Leathers TD, Punnapayak H. Heavy oils produced by Aureobasidium pullulans. Biotechnol Lett. 2011;33(6):1151-7.

110. Pham TLH, Zaspel I, Schuemann M, Stephanowitz H, Krause E. Rapid in vitro and in vivo detection of Chalara fraxinea by means of mass spectrometric techniques. Am J Plant Sci. 2013;4(2A):444-53.

111. Abreu LM, Moreira GM, Ferreira D, Rodrigues-Filho E, Pfenning LH. Diversity of Clonostachys species assessed by molecular phylogenetics and MALDI-TOF mass spectrometry. Fungal Biol. 2014;118(12):1004-12.
112. Chang S, Porto Carneiro-Leao M, Ferreira de Oliveira B, Souza-Motta C, Lima N, Santos C, et al. Polyphasic approach including MALDI-TOF MS/ MS analysis for identification and characterisation of Fusarium verticillioides in Brazilian corn kernels. Toxins (Basel). 2016;8(3):54.

113. Marchetti-Deschmann M, Winkler W, Dong HJ, Lohninger H, Kubicek CP, Allmaier G. Using spores for Fusarium spp. classification by MALDIbased intact cell/spore mass spectrometry. Food Technol Biotech. 2012;50(3):334-42.

114. Dong H, Marchetti-Deschmann M, Winkler W, Lohninger H, Allmaier G. Intact cell/spore mass spectrometry of Fusarium macro conidia for fast isolate and species differentiation. In: Banoub J, editor. Detection of biological agents for the prevention of bioterrorism. NATO Science for Peace and Security Series A: Chemistry and Biology: Springer Netherlands; 2011. p. 47-63.

115. Dong H, Kemptner J, Marchetti-Deschmann M, Kubicek CP, Allmaier G. Development of a MALDI two-layer volume sample preparation technique for analysis of colored conidia spores of Fusarium by MALDI linear TOF mass spectrometry. Anal Bioanal Chem. 2009;395(5):1373-83.

116. Kemptner J, Marchetti-Deschmann M, Kubicek CP, Allmaier G. Mixed volume sample preparation method for intact cell mass spectrometry of Fusarium spores. J Mass Spectrom. 2009;44(11):1622-4.

117. Kemptner J, Marchetti-Deschmann M, Mach R, Druzhinina IS, Kubicek CP, Allmaier G. Evaluation of matrix-assisted laser desorption/ionization (MALDI) preparation techniques for surface characterization of intact Fusarium spores by MALDI linear time-of-flight mass spectrometry. Rapid Commun Mass Spectrom. 2009;23(6):877-84.

118. Dong H, Marchetti-Deschmann M, Allmaier G. Characterization of on-target generated tryptic peptides from Giberella zeae conidia spore proteins by means of matrix-assisted laser desorption/ionization mass spectrometry. Mol Cell Probes. 2014;28(2-3):91-8.

119. Lopes RB, Faria M, Souza DA, Bloch C Jr, Silva LP, Humber RA. MALDITOF mass spectrometry applied to identifying species of insectpathogenic fungi from the Metarhizium anisopliae complex. Mycologia. 2014;106(4):865-78.

120. Horka M, Kubesova A, Salplachta J, Zapletalova E, Horky J, Slais K. Capillary and gel electromigration techniques and MALDI-TOF MSsuitable tools for identification of filamentous fungi. Anal Chim Acta. 2012;716:155-62.

121. Hettick JM, Green BJ, Buskirk AD, Kashon ML, Slaven JE, Janotka E, et al. Discrimination of Penicillium isolates by matrix-assisted laser desorption/ionization time-of-flight mass spectrometry fingerprinting. Rapid Commun Mass Spectrom. 2008;22(16):2555-60.

122. Chen HY, Chen YC. Characterization of intact Penicillium spores by matrix-assisted laser desorption/ionization mass spectrometry. Rapid Commun Mass Spectrom. 2005;19(23):3564-8.

123. Beinhauer J, Raus M, Hanzalova A, Horcicka P, Sebela M. Intact spore MALDI-TOF mass spectrometry and proteomic analysis of Puccinia pathogenic fungi. Biochim Biophys Acta. 2016;1864(9):1093-103.

124. Valentine NB, Wahl JH, Kingsley MT, Wahl KL. Direct surface analysis of fungal species by matrix-assisted laser desorption/ionization mass spectrometry. Rapid Commun Mass Spectrom. 2002;16(14):1352-7.

125. Amiri-Eliasi B, Fenselau C. Characterization of protein biomarkers desorbed by MALDI from whole fungal cells. Anal Chem. 2001;73(21):5228-31.

126. Neuhof T, Berg A, Besl H, Schwecke T, Dieckmann R, von Döhren H. Peptaibol production by Sepedonium strains parasitizing Boletales. Chem Biodivers. 2007:4(6):1103-15.

127. De Respinis S, Vogel G, Benagli C, Tonolla M, Petrini O, Samuels GJ. MALDI-TOF MS of Trichoderma: a model system for the identification of microfungi. Mycol Prog. 2010;9(1):79-100.

128. Degenkolb T, Diekmann R, Nielsen KF, Gräfenhan T, Theis C, Zafari $D$, et al. The Trichoderma brevicompactum clade: a separate lineage with new species, new peptaibiotics, and mycotoxins. Mycol Prog. 2008;7:177-219.

129. Neuhof T, Dieckmann R, Druzhinina IS, Kubicek CP, von Döhren H. Intactcell MALDI-TOF mass spectrometry analysis of peptaibol formation by the genus Trichoderma/Hypocrea: can molecular phylogeny of species predict peptaibol structures? Microbiology. 2007;153(Pt 10):3417-37. 
130. Neuhof T, Dieckmann R, Druzhinina IS, Kubicek CP, Nakari-Setala $T$, von Döhren $\mathrm{H}$. Direct identification of hydrophobins and their processing in Trichoderma using intact-cell MALDI-TOF MS. FEBS J. 2007;274(3):841-52

131. Holzlechner M, Reitschmidt S, Gruber S, Zeilinger S, MarchettiDeschmann M. Visualizing fungal metabolites during mycoparasitic interaction by MALDI mass spectrometry imaging. Proteomics. 2016;16(11-12):1742-6.

132. Tao J, Zhang G, Jiang Z, Cheng Y, Feng J, Chen Z. Detection of pathogenic Verticillium spp. using matrix-assisted laser desorption/ionization time-of-flight mass spectrometry. Rapid Commun Mass Spectrom. 2009;23(23):3647-54.
133. Schmidt O, Kallow W. Differentiation of indoor wood decay fungi with MALDI-TOF mass spectrometry. Holzforschung. 2005;59:374-7.

134. Stubiger G, Wuczkowski M, Mancera L, Lopandic K, Sterflinger K, Belgacem $O$. Characterization of yeasts and filamentous fungi using MALDI lipid phenotyping. J Microbiol Methods. 2016;130:27-37.

\section{Submit your manuscript to a SpringerOpen ${ }^{\circ}$ journal and benefit from:}

- Convenient online submission

\section{- Rigorous peer review}

Immediate publication on acceptance

- Open access: articles freely available online

- High visibility within the field

- Retaining the copyright to your article 